\title{
Strain Selection and Optimization of Mixed Culture Conditions for Lactobacillus pentosus K1-23 with Antibacterial Activity and Aureobasidium pullulans NRRL 58012 Producing Immune-Enhancing $\beta$-Glucan's
}

\author{
Ashokkumar Sekar ${ }^{1}$, Myoungjin Kim ${ }^{1}$, Hyeong Chul Jeong ${ }^{2}$, and Keun Kim ${ }^{1 *}$ \\ ${ }^{1}$ Division of Bio-industry, University of Suwon, Hwaseong 18323, Republic of Korea \\ ${ }^{2}$ Division of Data-science, University of Suwon, Hwaseong 18323, Republic of Korea
}

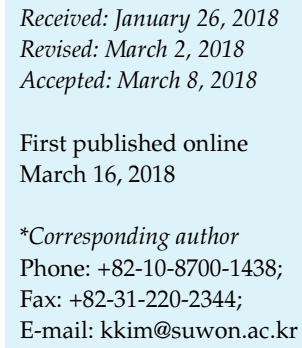

S upplementary data for this paper are available on-line only at http://jmb.or.kr.

pISSN 1017-7825, eISSN 1738-8872

Copyright(C) 2018 by

The Korean Society for Microbiology and Biotechnology
Lactobacillus pentosus K1-23 was selected from among 25 lactic acid bacterial strains owing to its high inhibitory activity against several pathogenic bacteria, including Escherichia coli, Salmonella typhimurium, S. gallinarum, Staphylococcus aureus, Pseudomonas aeruginosa, Clostridium perfringens, and Listeria monocytogenes. Additionally, among 13 strains of Aureobasidium spp., A. pullulans NRRL 58012 was shown to produce the highest amount of $\beta$-glucan $(15.45 \pm$ $0.07 \%$ ) and was selected. Next, the optimal conditions for a solid-phase mixed culture with these two different microorganisms (one bacterium and one yeast) were determined. The optimal inoculum sizes for L. pentosus and A. pullulans were $1 \%$ and $5 \%$, respectively. The appropriate inoculation time for L. pentosus K1-23 was 3 days after the inoculation of A. pullulans to initiate fermentation. The addition of $0.5 \%$ corn steep powder and $0.1 \% \mathrm{FeSO}_{4}$ to the basal medium resulted in the increased production of lactic acid bacterial cells and $\beta$-glucan. The following optimal conditions for solid-phase mixed culture were also statistically determined by using the response surface method: $37.84^{\circ} \mathrm{C}, \mathrm{pH} 5.25$, moisture content of $60.82 \%$, and culture time of 6.08 days for L. pentosus; and $24.11^{\circ} \mathrm{C}, \mathrm{pH} 5.65$, moisture content of $60.08 \%$, and culture time of 5.71 days for A. pullulans. Using the predicted optimal conditions, the experimental production values of $L$. pentosus cells and $\beta$-glucan were $3.15 \pm$ $0.10 \times 10^{8} \mathrm{CFU} / \mathrm{g}$ and $13.41 \pm 0.04 \%$, respectively. This mixed culture may function as a highly efficient antibiotic substitute based on the combined action of its anti-pathogenic bacterial and immune-enhancing activities.

Keywords: Aureobasidium, immune-enhancing $\beta$-glucan, Lactobacillus, anti-pathogenic activity, mixed culture

\section{Introduction}

Antibiotics are chemotherapeutic agents used for the clinical management of infectious diseases in humans and animals. Antibiotics have been added to animal feed to enhance agricultural and aquatic productivity. However, owing to increased consumer concerns regarding food safety and the appearance of super-bacteria, the use of antibiotics in animal feed has been regulated. Recently, the use of antibiotics to promote animal growth was completely banned in Korea. However, the regulation of antibiotic use in animal feed has led to a decrease in productivity due to increased mortality; therefore, the development of antibiotic alternatives is essential.

Probiotics promote beneficial microbial growth while inhibiting pathogenic microorganisms, promote animal growth, and improve feed efficiency. Probiotics also prevent intestinal diseases in young animals owing to intestinal microbial competition, reduce pathogenic microorganisms, and improve immune function [1, 2]. Lactic acid bacteria 
(LAB) are the most widely used probiotics, and Lactobacillus and Bifidobacterium are the safest species and have been studied by many researchers [3]. The antimicrobial effects of LAB include the production of low $\mathrm{pH}$, organic acids, bacteriocins, carbon dioxide, ethanol, diacetyl, low-molecularweight antimicrobials, low reduction potential, nutrient depletion, and dominance [4].

Physiologically active polysaccharides produced by bacteria, yeast, and molds are used in a variety of industrial applications, including pharmaceuticals, cosmetics, and the food industry, and many polysaccharides have been reported to exhibit antioxidant, antitumor, antiviral, antiinflammatory, and immune system-enhancing effects [5-7]. $\beta$-Glucan, a well-known physiologically active polysaccharide, is a chain-type polysaccharide in which glucose molecules are linked by $\beta$-D-glycosidic bonds. $\beta$-Glucan is mainly present in the form of $\beta$-(1,3)-glucan or $\beta-(1,6)$-glucan in yeast and mushrooms and in the form of $\beta-(1,3)$-glucan and $\beta$-(1,4)-glucan in oat and barley [8]. $\beta-(1,3),(1,6)$-Glucan is a branched $\beta$-glucan form in which a glucose (s) is connected to the main chain by a $\beta-(1,6)$-glycosidic bond. $\beta-(1,3),(1,6)$ Glucan exerts antitumor [9], anti-infectious disease [10], and anti-inflammation [11] effects by regulating the immune system.

Aureobasidium pullulans, also known as black yeast, is a polymorphic fungus that is widespread in nature. A. pullulans produces complex exopolysaccharides, including pullulan ( $\alpha$-glucan), which is used in the pharmaceutical industry [12]. $\beta-(1,3),(1,6)$-Glucan derived from A. pullulans cultures has been recognized as a food additive and is consumed as a health-promoting food in many countries [13]. When producing health supplements containing $\beta-(1,3),(1,6)$ glucan from other organisms, an extraction process, such as hot water extraction, is required. However, $\beta-(1,3),(1,6)$ glucan produced by $A$. pullulans is water-soluble and therefore can be used as a food additive without requiring an extraction process. $\beta$ - $(1,3)$ or $(1,6)$-glucan produced from mushrooms has a high molecular mass $(\sim 2,000 \mathrm{kDa})$ and is insoluble in water [14], but $\beta-(1,3),(1,6)$-glucan of $A$. pullulans consists of small molecules approximately $100 \mathrm{kDa}$ in size that are soluble in water [15].

In addition to the advantages described above, $\beta-(1,3),(1,6)-$ glucan produced by $A$. pullulans has nearly the same efficacy as the same type of glucan produced in other organisms. For example, $\beta-(1,3),(1,6)$-glucan produced by A. pullulans has been shown to be effective against cancer $[16,17]$ and to demonstrate anti-allergy [6] and influenzapreventing activities [13].

Existing technology has been effective for commercializing a variety of antibiotic substitute materials such as enzymes, probiotics, acidifiers, and plant extracts. However, single materials have limited efficacy and have not shown good results. Therefore, in the present study, we combined two different materials with different modes of action against pathogens to develop a more efficient antibiotic substitute. In the present study, we selected a LAB strain with high anti-pathogenic activity and an A. pullulans strain producing a high amount of immune-enhancing $\beta$-glucan. The optimal culture conditions for solid-phase mixed culture of these two different microorganisms (a bacterium and a yeast) were examined. This mixed culture may function as a highly efficient antibiotic substitute, based on the combined effects of its anti-pathogenic and immune-enhancing activities.

\section{Materials and Methods}

\section{LAB and A. pullulans Strains}

The 25 LAB strains exhibiting high antibacterial activity against various pathogenic bacteria were our laboratory stock cultures. These $25 \mathrm{LAB}$ were previously selected for their anti-pathogenic bacterial activity from among 800 isolates derived from natural sources. The 13 strains of $A$. pullulans used in this study are shown in Table 1.

\section{Pathogenic Bacteria and Cultures}

Different pathogenic bacteria and their respective culture media (shown in parenthesis) used in the study included Escherichia coli (Luria-Bertani broth), Salmonella typhimurium, S. gallinarum (tryptic soy broth), Staphylococcus aureus (nutrient broth), Pseudomonas aeruginosa (nutrient broth), Clostridium perfringens (reinforced clostridial medium), and Listeria monocytogenes (brain heart infusion medium); all media were BD Difco (USA) products. The bacteria were cultured in $100 \mathrm{ml}$ of liquid medium in a $250-\mathrm{ml}$ flask at $37^{\circ} \mathrm{C}$ for 1 day.

\section{Minimum Inhibitory Concentration (MIC)}

LAB were inoculated into MRS broth and cultured under anaerobic incubation at $37^{\circ} \mathrm{C}$ for 1 day. The cultures were centrifuged at 9,000 $\times g$, the supernatants were filtered through a $0.45-\mu \mathrm{m}$ syringe filter, and the filtrates were twice subjected to serial dilution with MRS broth. Each pathogenic bacterium was cultured in broth at $37^{\circ} \mathrm{C}$ for 1 day, diluted with physiological saline, and adjusted to $1 \times 10^{6} \mathrm{CFU} / \mathrm{ml}$. Two hundred microliters of a mixed solution consisting of $10 \%$ diluted LAB culture filtrate, $5 \%$ pathogenic bacterial culture $\left(1 \times 10^{6} \mathrm{CFU} / \mathrm{ml}\right)$, and $85 \%$ culture medium for each pathogen was placed in a 96-well plate and incubated at $37^{\circ} \mathrm{C}$ for 1 day under aerobic condition. The MIC (concentration of LAB culture filtrate in $200 \mu$ l of total mixed solution) represented the minimum concentration of the diluted solution of the LAB culture filtrate in which pathogenic bacteria did not proliferate. 
Table 1. List of Aureobasidium strains used in this study.

\begin{tabular}{lll}
\hline \multicolumn{1}{c}{ Strain } & Scientific name & \multicolumn{1}{c}{ Source } \\
\hline YH & $\begin{array}{l}\text { A. pullulans } \\
\text { A. pullulans }\end{array}$ & Laboratory stock culture \\
CU30 & A. pullulans & $\begin{array}{l}\text { H. Punnapayak \& S. Prasongsuk } \\
\text { Chulalongkorn Univ. Thailand }\end{array}$ \\
YR & A.pullulans & $\begin{array}{l}\text { H. Punnapayak \& S. Prasongsuk } \\
\text { Chulalongkorn Univ. Thailand }\end{array}$ \\
KACC 41291 & A. pullulans & Laboratory stock culture \\
KACC 43382 & A. pullulans & Korean Agricultural Culture Collection \\
KCCM 12017 & A.pullulans & Korean Agricultural Culture Collection \\
NRRL 58012 & A. pullulans & Korean Culture Center of Microorganisms \\
NRRL 58013 & A. pullulans & ARS Culture Collection (NRRL), USA \\
NRRL 58522 & A. pullulans & ARS Culture Collection (NRRL), USA \\
NRRL 58539 & Aureobasidum sp. & ARS Culture Collection (NRRL), USA \\
NRRL 58543 & Aureobasidum sp. & ARS Culture Collection (NRRL), USA \\
NRRL 62100 & A. pullulans & ARS Culture Collection (NRRL), USA \\
\hline
\end{tabular}

\section{A. pullulans Culture}

The liquid medium for A. pullulans was glucose-sucrose (GS) medium containing $2.5 \%$ glucose, $2.5 \%$ sucrose, $0.2 \%$ ascorbic acid, $0.1 \% \mathrm{~K}_{2} \mathrm{HPO}_{4}, 0.2 \% \mathrm{MgSO}_{4} \cdot 7 \mathrm{H}_{2} \mathrm{O}$, and $1.0 \%$ corn steep liquor. One loopful of culture was inoculated into a 250-ml Erlenmeyer flask containing $50 \mathrm{ml}$ of GS and cultured for 5 days at $25^{\circ} \mathrm{C}$ and $200 \mathrm{rpm}$. The solid medium for $\beta$-glucan production consisted of $8 \%$ molasses, $0.2 \%$ ascorbic acid, $3 \%$ amino acid fermentation waste (Daesang co., Ltd, Korea), and $88.8 \%$ soybean powder. GS broth cultured for 3 days was inoculated into solid medium, mixed well, and cultured at $25^{\circ} \mathrm{C}$ for 5 days.

\section{Analysis of Glucan in Solid Culture Medium}

Total glucan and $\beta$-glucan contents were measured in solid culture using a $\beta$-glucan assay kit (Megazyme International Ireland Ltd., Ireland). For pretreatment, the solid culture was mixed well, and $100 \mathrm{mg}$ of culture was added to a conical flask with $1.5 \mathrm{ml}$ of $37 \%$ hydrochloric acid. The mixture was stirred for $45 \mathrm{~min}$ in a $37^{\circ} \mathrm{C}$ water bath, and then $10 \mathrm{ml}$ distilled water was added and hydrolysis was carried out for $2 \mathrm{~h}$ at $100^{\circ} \mathrm{C}$. The hydrolyzate was cooled down and neutralized by adding $10 \mathrm{ml}$ of $2 \mathrm{~N} \mathrm{KOH}$ and centrifuged at $3,000 \times g$ to obtain a supernatant. For total glucan analysis, $0.1 \mathrm{ml}$ of exo-1,3- $\beta$-glucosidase plus $\beta$-glucosidase was added to $0.1 \mathrm{ml}$ of pretreated supernatant, and the reaction was carried out at $40^{\circ} \mathrm{C}$ for $60 \mathrm{~min}$ to decompose total glucan into glucose. Glucose was assayed by the DNS method [18], and the total amount of glucan was calculated from the amount of glucose produced.

For $\alpha$-glucan analysis, $100 \mathrm{mg}$ of well-mixed solid culture was added to a test tube, followed by the addition of $2 \mathrm{ml}$ of $2 \mathrm{M} \mathrm{KOH}$, and the mixture was stirred for $20 \mathrm{~min}$; then, $8 \mathrm{ml}$ of $1.2 \mathrm{M}$ sodium acetate buffer $(\mathrm{pH} 3.8)$ and $0.2 \mathrm{ml}$ of amyloglucosidase plus invertase were added. The reaction was carried out in a $40^{\circ} \mathrm{C}$ water bath for $30 \mathrm{~min}$. The reaction solution was centrifuged, the amount of glucose in the supernatant was quantified by DNS, and the amount of $\alpha$-glucan was calculated from the produced glucose. The $\beta$-glucan content was calculated by subtracting the $\alpha$-glucan content from the total glucan content.

\section{Identification of Microorganisms}

The final selected LAB strain was identified using 16S rRNA gene sequencing. PCR (PCR system 2700; GeneAmp Co., Singapore) was performed using 27F (5'-GATTTGGATCCT GGCTCAG-3') and 1492R (5'-AAGGAGGGGATCCAGCC-3') as PCR primers. The PCR mixture consisted of $2 \mu$ of template DNA, $1 \mu \mathrm{l}$ of $27 \mathrm{Fprimer}$, and $1 \mu \mathrm{l}$ of $1492 \mathrm{R}$ primer in a total volume of $20 \mu \mathrm{l}$. The following PCR conditions were used: initial denaturation at $94^{\circ} \mathrm{C}$ for $2 \mathrm{~min}$, denaturation at $94^{\circ} \mathrm{C}$ for $20 \mathrm{sec}$, annealing at $60^{\circ} \mathrm{C}$ for $20 \mathrm{sec}$, and extension at $72^{\circ} \mathrm{C}$ for $1 \mathrm{~min}$ and $30 \mathrm{sec}$. The PCR was performed for 30 cycles, after which final extension was carried out at $72^{\circ} \mathrm{C}$ for $5 \mathrm{~min}$. The PCR products were purified using a QIA Quick PCR purification kit (Qiagen, USA), and DNA sequencing analysis was performed by a commercial company (Biomedic Co., Ltd, Korea). An NCBI BLAST homology search (BLASTN) [19] using the obtained sequences was used to identify the LAB.

For yeast strain identification, genomic DNA was extracted [20], and ITS1 (5'-TCC GTA GGT GAA CCT GCG G-3') and ITS4 (5'-TCC TCC GCT TAT TGA TAT GC-3') primers were used for PCR amplification of the ITS region [21]. The DNA was amplified using the procedure of Gardes and Bruns [22]. The purification, DNA sequencing analysis of the PCR products, and subsequent identification were performed in the same manner as described for LAB. 
Solid-Phase Mixed Culture of LAB and A. pullulans

$\mathrm{LAB}$ was cultured in MRS broth at $37^{\circ} \mathrm{C}$ for 1 day, and A. pullulans was grown in GS broth at $25^{\circ} \mathrm{C}$ for 5 days. A $1 \% \mathrm{LAB}$ culture and a $5 \%$ A. pullulans culture were inoculated into solid medium and incubated at $25^{\circ} \mathrm{C}$ for 5 days. The LAB numbers and $\beta$-glucan content were measured.

\section{Inoculation Time and Optimization of $\beta$-Glucan Production}

Considering the short culture period of $\mathrm{LAB}$, we first inoculated A. pullulans into solid medium and later inoculated the LAB at 1-day intervals to find the optimal LAB inoculation point for the $\mathrm{LAB}$ cells and $\beta$-glucan production.

\section{Effects of Medium Components on LAB Cells and $\beta$-Glucan}

In our previous study, the concentrations of amino waste solution and soybean powder in basic solid medium ( $8 \%$ molasses, $0.2 \%$ ascorbic acid, $3 \%$ amino acid waste solution, $88.8 \%$ soybean powder, and $70 \%$ moisture content) were optimized [23]. In this study, different nitrogen sources, minerals, and concentrations of ascorbic acid were added to the basic solid medium for inoculation and cultured at $25^{\circ} \mathrm{C}$ for 5 days; then, LAB cell counts and $\beta$-glucan contents were determined.

Nitrogen sources: $0.5 \% \mathrm{NaNO}_{3}, \mathrm{NH}_{4} \mathrm{Cl}$, urea, soybean meal, corn steep powder (CSP), or skim milk were added to the basic solid medium.

Minerals: After $0.5 \%$ CSP was added to the basic solid medium, $0.1 \% \mathrm{MgSO}_{4}, \mathrm{MnCl}_{2}, \mathrm{CuSO}_{4}, \mathrm{FeSO}_{4}, \mathrm{ZnSO}_{4}$, or $\mathrm{CaCl}_{2}$ was added to the medium.

Ascorbic acid: $0.0 \%, 0.1 \%, 0.2 \%, 0.3 \%$, or $0.4 \%$ ascorbic acid was added to the basic medium containing $0.5 \% \mathrm{CSP}$ and $0.1 \% \mathrm{FeSO}_{4}$.

\section{Optimization of Mixed Culture Conditions by Using a Statistical Method}

To optimize the culture conditions for the solid medium, statistical optimization was performed by varying the moisture content, temperature, $\mathrm{pH}$, and culture days. An experiment was

Table 2. Minimum inhibitory concentrations (MIC, \%) of various LAB culture supernatants.

\begin{tabular}{|c|c|c|c|c|c|c|c|}
\hline \multirow{2}{*}{ Strain } & \multicolumn{7}{|c|}{ MIC (\%) } \\
\hline & E. coli & S. typhimurium & S. gallinarum & S. aureus & P. aeruginosa & C. perfringens & L. monocytogenes \\
\hline K1-1 & 5 & 5 & 1.25 & 10 & 1.25 & 10 & 10 \\
\hline $\mathrm{K} 1-3$ & 2.5 & 10 & 1.25 & 10 & 1.25 & 10 & 10 \\
\hline $\mathrm{K} 1-5$ & 1.25 & 10 & 5 & 10 & 5 & 10 & 10 \\
\hline K1-6 & 5 & 5 & 2.5 & 10 & 1.25 & 10 & 5 \\
\hline K1-7 & 5 & 2.5 & 1.25 & 5 & 1.25 & 5 & 10 \\
\hline $\mathrm{K} 1-8$ & 5 & 10 & 5 & 10 & 5 & 10 & 10 \\
\hline K1-9 & 5 & 5 & 2.5 & 10 & 5 & 5 & 5 \\
\hline K1-10 & 2.5 & 10 & 1.25 & 10 & 5 & 10 & $>10$ \\
\hline K1-11 & 1.25 & 5 & 2.5 & 5 & 5 & 2.5 & 5 \\
\hline K1-13 & 5 & 2.5 & 5 & 10 & 5 & 10 & 10 \\
\hline K1-15 & 5 & 2.5 & 5 & 10 & 2.5 & 10 & $>10$ \\
\hline K1-16 & 5 & 5 & 5 & 5 & 2.5 & 10 & 5 \\
\hline K1-17 & 2.5 & 10 & 1.25 & 10 & 1.25 & 10 & 10 \\
\hline K1-18 & 5 & 10 & 1.25 & 5 & 1.25 & 5 & 10 \\
\hline K1-19 & 2.5 & 2.5 & 1.25 & 5 & 1.25 & 2.5 & 5 \\
\hline $\mathrm{K} 1-20$ & 2.5 & 10 & 5 & 10 & 2.5 & 5 & 5 \\
\hline K1-21 & 5 & 10 & 2.5 & 10 & 1.25 & 10 & 10 \\
\hline K1-22 & 5 & 10 & 2.5 & 5 & 1.25 & 5 & 5 \\
\hline K1-23 & 1.25 & 2.5 & 1.25 & 5 & 1.25 & 2.5 & 10 \\
\hline K2-4 & 10 & 10 & 5 & 5 & 1.25 & 2.5 & 10 \\
\hline K5-3 & 10 & 10 & 10 & 10 & 10 & 5 & 10 \\
\hline K5-5 & 10 & 10 & 2.5 & 5 & 5 & 10 & 10 \\
\hline
\end{tabular}


performed using the response surface methodology (RSM) with four factors (Table S1). A central composite design (CCD) was used to determine the design points. Sixteen points for factorial experiments, eight points for the axis point, and six points for the central point were required by the CCD design.

The second-order regression model is as follows:

$$
Y=\beta_{0}+\sum_{i} \beta_{i} X_{i}+\sum_{i} \beta_{i i} X_{i}^{2}+\sum_{i<j} \beta_{i j} X_{i} X_{j}
$$

where $Y$ is the estimated response value, $X_{i}$ is the coded variable, $\beta_{0}$ is the intercept, $\beta_{i}$ is the first-order coefficient, $\beta_{i i}$ is the secondorder coefficient, and $\beta_{i j}$ is the interaction coefficient between $X_{i}$ and $X_{j}$.

On the other hand, note that $X_{i}$ has the following relationship:

$$
X_{i}=\frac{x_{i}-x_{0}}{\nabla x_{i}}
$$

where $X_{i}$ is the coded value, $x_{i}$ is the actual value, $x_{0}$ is the center value, and $\nabla x_{i}$ is the increment value. Eq. (1) shows a regression model with coded variables. $X_{i}$ is encoded into one of the following five values: $\pm 2, \pm 1$, and 0 . Table 2 shows the actual and coded values for the four factors used in this study. The optimal experimental levels for LAB cell numbers and $\beta$-glucan production were investigated by using RSM.

\section{Results and Discussion}

\section{Selection of LAB for Anti-Pathogenic Activity}

The MICs of 25 LAB strains were examined, and the results are shown in Table 2. Fifteen strains (K1-1, K1-3, K15, K1-6, K1-7, K1-10, K1-11, K1-13, K1-15, K1-17, K1-18, K1$19, \mathrm{~K} 1-21, \mathrm{~K} 1-22$, and K1-23) were selected on the basis of their MICs, and these strains were used in mixed culture with $A$. pullulans for further selection.

\section{Selection of $A$. pullulans Producing $\beta$-Glucan}

Thirteen strains of $A$. pullulans were examined for their $\beta$-glucan production on solid culture medium, and A. pullulans NRRL 58012 produced the highest amounts of $\beta$-glucan (15.45 $\pm 0.07 \%$ ) and was selected (Table S2).

\section{Final Selection of LAB for Mixed Culture}

In a solid-phase mixed culture with $A$. pullulans, the highest amounts of $\beta$-glucan (12.4-12.7\%) were produced by K113, K1-19, and K1-23 (Table 3). In mixed culture, LAB K1-15 produced the highest cell numbers $\left(2.75 \times 10^{8} \mathrm{CFU} / \mathrm{g}\right)$, but its $\beta$-glucan production was low (9.6\%). In all mixed cultures, $\beta$-glucan production was less than $14.4 \%$ of the control with no LAB inoculation. LAB K1-23 was selected because this strain satisfied the requirements for high production of
Table 3. Production of $L A B$ cells and $\beta$-glucan by solid-phase mixed cultures of various LAB strains ${ }^{\mathrm{a}}$ and $A$. pullulans NRRL

\begin{tabular}{|c|c|c|c|c|}
\hline \multirow{2}{*}{$\begin{array}{l}\text { LAB } \\
\text { strain }\end{array}$} & \multirow{2}{*}{$\begin{array}{c}\text { LAB viable } \\
\text { cell no. } \\
\left(\times 10^{8} \mathrm{CFU} / \mathrm{g}\right)\end{array}$} & \multicolumn{3}{|c|}{ Concentration $(\%, \mathrm{w} / \mathrm{w})$} \\
\hline & & Total glucan & $\alpha$-Glucan & $\beta$-Glucan \\
\hline Control & 0 & 21.1 & 6.7 & 14.4 \\
\hline K1-1 & 2.21 & 15.6 & 9.5 & 6.1 \\
\hline $\mathrm{K} 1-3$ & 1.32 & 20.3 & 8.6 & 11.6 \\
\hline $\mathrm{K} 1-5$ & 2.04 & 17.8 & 9.3 & 8.5 \\
\hline K1-6 & 2.57 & 13.2 & 11.3 & 1.9 \\
\hline $\mathrm{K} 1-7$ & 0.35 & 16.5 & 10.3 & 6.2 \\
\hline K1-10 & 1.21 & 19.2 & 8.7 & 10.5 \\
\hline K1-11 & 1.38 & 20.0 & 9.2 & 10.8 \\
\hline K1-13 & 0.93 & 21.2 & 8.5 & 12.7 \\
\hline K1-15 & 2.75 & 19.5 & 9.9 & 9.6 \\
\hline K1-17 & 2.42 & 19.4 & 9.5 & 9.9 \\
\hline K1-18 & 1.66 & 18.9 & 10.2 & 8.7 \\
\hline K1-19 & 2.01 & 20.5 & 8.1 & 12.4 \\
\hline K1-21 & 1.36 & 19.7 & 9.5 & 10.2 \\
\hline K1-22 & 1.75 & 20.1 & 8.8 & 11.3 \\
\hline K1-23 & 2.35 & 20.8 & 8.3 & 12.5 \\
\hline
\end{tabular}
$58012^{\mathrm{b}}$.

${ }^{\mathrm{a}} \mathrm{LAB}$ strains were grown in MRS broth for $24 \mathrm{~h}$ at $37^{\circ} \mathrm{C}$.

${ }^{\mathrm{b}}$ A. pullulans NRRL 58012 was grown in glucose-sucrose broth for $24 \mathrm{~h}$ at $25^{\circ} \mathrm{C}$.

both LAB cell numbers $\left(2.35 \times 10^{8} \mathrm{CFU} / \mathrm{g}\right)$ and $\beta$-glucan (12.5\%). LAB K1-23 was identified as Lactobacillus pentosus. L. pentosus was first isolated from human feces and has been used to produce probiotics [24] as well as bacteriocins and inhibits pathogens such as E. coli, Pseudomonas aeruginosa, and Klebsiella pneumoniae [25].

\section{Effects of Inoculum Size on LAB Cell Numbers and $\beta$-Glucan Production in Mixed Culture}

The effects of inoculum size on $L$. pentosus K1-23 cell numbers and $\beta$-glucan production by $A$. pullulans NRRL 58012 in mixed solid-phase culture were examined, and the results are shown in Table S3. With different inoculum sizes $(1 \%, 5 \%, 10 \%)$ of $L$. pentosus, the average number of $\mathrm{LAB}$ cells was $2.67 \pm 0.19 \times 10^{8} \mathrm{CFU} / \mathrm{g}$, and differences in LAB cell production were not significant. Whereas $10 \%$ L. pentosus inoculum produced a lowered amount of $\beta$-glucan, there was no difference in $\beta$-glucan production between $1 \%$ and $5 \%$ L. pentosus inoculums. With different inoculum sizes $(1 \%, 5 \%, 10 \%)$ of $A$. pullulans, differences in LAB cell production were not observed. Our previous statistical study showed that inoculum size did not significantly 
affect $\beta$-glucan production by $A$. pullulans [23]. The best combination of inocula was $1 \%$ L. pentosus and $5 \%$ A. pullulans, from which $2.51 \times 10^{8} \mathrm{CFU} / \mathrm{g}$ and $12.9 \%$ $\beta$-glucan were produced, respectively.

\section{Differential Inoculation Times for L. pentosus K1-23 in a Mixed Culture}

Thus far, in these mixed culture experiments, the two microorganisms were inoculated at the beginning of the mixed culture and incubated for 5 days. Since L. pentosus $\mathrm{K} 1-23$ cells grow significantly faster and its culture time is shorter than that of $A$. pullulans NRRL 58012, L. pentosus could be inoculated later than $A$. pullulans. The optimal inoculation time for $L$. pentosus was determined by inoculating L. pentosus at 1-day intervals, and the results are shown in Fig. 1.

When the two strains were inoculated simultaneously at day 0 , the final number of L. pentosus cells was $2.52 \times$ $10^{8} \mathrm{CFU} / \mathrm{g}$, followed by $2.38 \times 10^{8} \mathrm{CFU} / \mathrm{g}$ on day $1,2.31 \times$ $10^{8} \mathrm{CFU} / \mathrm{g}$ on day $2,2.35 \times 10^{8} \mathrm{CFU} / \mathrm{g}$ on day 3 , and $2.21 \times$ $10^{8} \mathrm{CFU} / \mathrm{g}$ on day 4 ; there was no significant difference in the number of final $L$. pentosus cells with different inoculation times. With earlier inoculation (day 0,1 , and 2) of $L$. pentosus, $\beta$-glucan production was significantly reduced prior to $120 \mathrm{~h}$ of culture. However, after $120 \mathrm{~h}$ of culture, $12.72-13.05 \% \quad \beta$-glucan was obtained, and the difference was not significant for different inoculation times. With L. pentosus inoculation on the $3^{\text {rd }}$ or $4^{\text {th }}$ day of A. pullulans

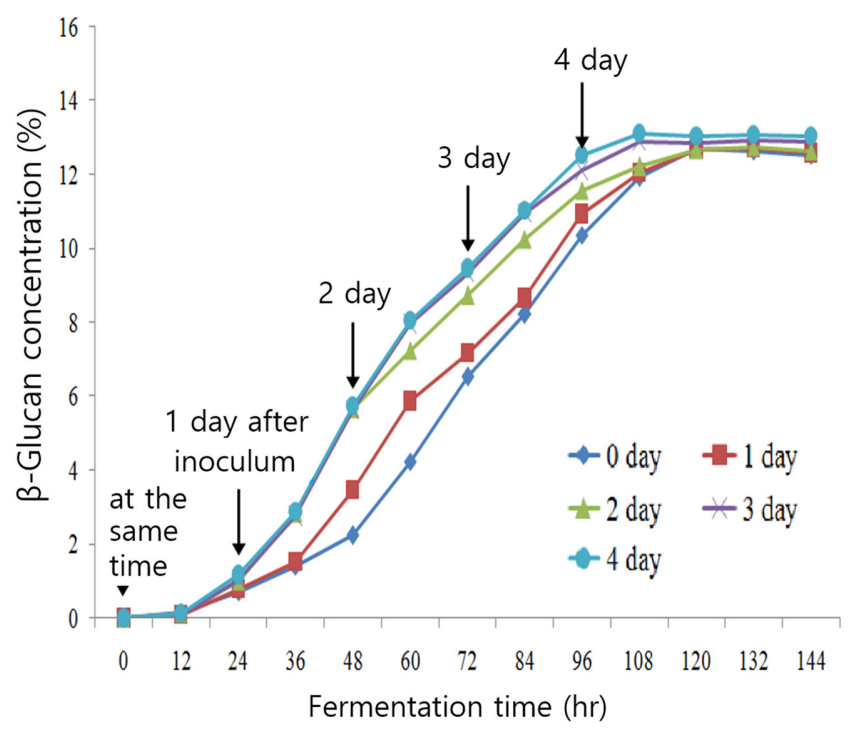

Fig. 1. Effect of $L$. pentosus K1-23 inoculation time on $\beta$-glucan production by $A$. pullulans NRRL 58012 in the solid-phase mixed culture. culture, maximum $\beta$-glucan production was achieved at $108 \mathrm{~h}$ instead of $120 \mathrm{~h}$ with earlier inoculation times; thus, it was possible to shorten the culture time by $12 \mathrm{~h}$.

\section{Optimization of Medium Composition for Mixed Culture}

Nitrogen source. With the addition of different nitrogen sources, the average total number of cells for L. pentosus $\mathrm{K} 1-23$ was $2.52 \pm 0.06 \times 10^{8} \mathrm{CFU} / \mathrm{g}$, and there were almost no differences in LAB cell numbers among the different nitrogen sources. $\beta$-Glucan production was $13.0 \pm 0.15 \%$ in the control group without the addition of nitrogen sources, and $13.2 \pm 0.17 \%$ and $13.1 \pm 0.10 \%$ when CSP and skim milk were added, respectively (Fig. 2A). CSP was selected because it produced relatively higher $\beta$-glucan levels and is a cheap medium component.

Minerals. $\beta$-Glucan production was slightly higher with the addition of $\mathrm{CuSO}_{4}(13.3 \pm 0.07 \%), \mathrm{FeSO}_{4}(13.4 \pm 0.14 \%)$, and $\mathrm{ZnSO}_{4}(13.3 \pm 0.14 \%)$ than in control culture (13.2 \pm $0.17 \%$ ) (Fig. 2B). The number of L. pentosus cells after the addition of different minerals varied from 2.33-2.93 $\times$ $10^{8} \mathrm{CFU} / \mathrm{g} . \mathrm{MgSO}_{4}, \mathrm{MnCl}_{2}$, and $\mathrm{CaCl}_{2}$ produced relatively higher LAB cell numbers $\left(2.80 \times 10^{8}, 2.93 \times 10^{8}\right.$, and $2.91 \times$ $10^{8} \mathrm{CFU} / \mathrm{g}$, respectively), but $\beta$-glucan production was
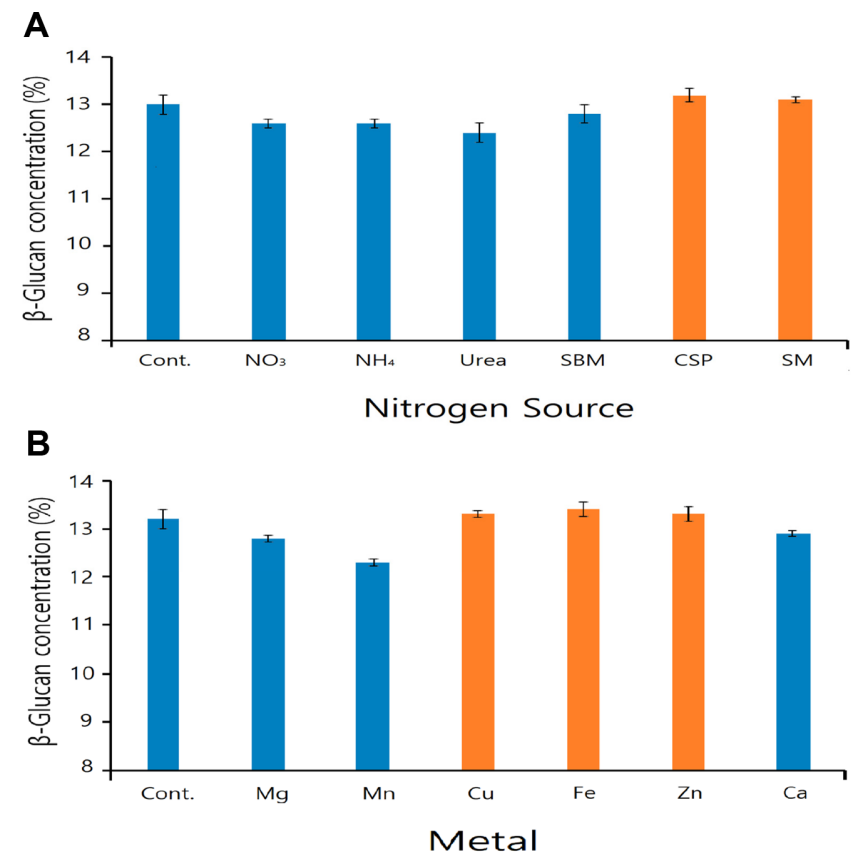

Fig. 2. Effects of different nitrogen sources (A) and minerals (B) on $\beta$-glucan production by A. pullulans NRRL 58012 in the solid-phase mixed culture with L. pentosus K1-23.

$\mathrm{SML}$, soy bean meal; CSP, corn steep liquor; $\mathrm{SM}$, skim milk; $\mathrm{Mg}$, $\mathrm{MgSO}_{4} ; \mathrm{Mn}, \mathrm{MnCl}_{2} ; \mathrm{Cu}, \mathrm{CuSO}_{4} ; \mathrm{Fe}, \mathrm{FeSO}_{4} ; \mathrm{Zn}, \mathrm{ZnSO}_{4} ; \mathrm{Ca}, \mathrm{CaCl}_{2}$. 
lower than that of the control group. We selected $\mathrm{FeSO}_{4}$, which produced the highest LAB cell numbers $(2.68 \times$ $\left.10^{8} \mathrm{CFU} / \mathrm{g}\right)$ as well as $\beta$-glucan $(13.4 \pm 0.14 \%)$. Gao et al. [26] reported that $\mathrm{K}_{2} \mathrm{HPO}_{4}$ is the most important mineral for cell growth and pullulan production.

Ascorbic acid. Different concentrations of ascorbic acid showed no difference in $\beta$-glucan production (13.39 \pm $0.01 \%)$ and LAB cell numbers $\left(2.63 \pm 0.05 \times 10^{8} \mathrm{CFU} / \mathrm{g}\right)$.

\section{Optimization of Culture Conditions Using a Statistical Method}

To determine the optimal conditions for solid-phase mixed culture, second-order regression models were generated by varying the temperature $\left(X_{1}\right), \mathrm{pH}\left(X_{2}\right)$, moisture content $\left(X_{3}\right)$, and culture time $\left(X_{4}\right)$. The experimental levels of LAB cell numbers and $\beta$-glucan production from the CCD experiment are shown in Table S4.

The second-order regression model for total LAB cell number was derived from Table S4 and is as follows:

$Y=2.563+0.188 X_{1}-0.010 X_{2}+0.043 X_{3}+0.485 X_{4}-$ $0.025 X_{1} X_{2}-0.000 X_{1} X_{3}+0.010 X_{1} X_{4}+0.018 X_{2} X_{3}-0.015 X_{2} X_{4}$ $+0.005 X_{3} X_{4}-0.021 X_{1}^{2}-0.103 X_{2}^{2}-0.108 X_{3}^{2}-0.253 X_{4}^{2}$

Fig. 3 is a response surface plot of the second-order regression. It is composed of six plots showing that L. pentosus cell production is affected by temperature and $\mathrm{pH}$, temperature and moisture content, temperature and culture time, $\mathrm{pH}$ and moisture content, and moisture content and culture time; there was a quadratic curve effect for the varying levels of each factor, leading to the optimal point. The optimal point derived by the surface response model equation was $37.84^{\circ} \mathrm{C}, \mathrm{pH} 5.25$, moisture content of $60.82 \%$, and 6.08 days, and the expected maximum value for L. pentosus cell numbers was $3.32 \times 10^{8} \mathrm{CFU} / \mathrm{g}$.

The second-order regression model for $\beta$-glucan
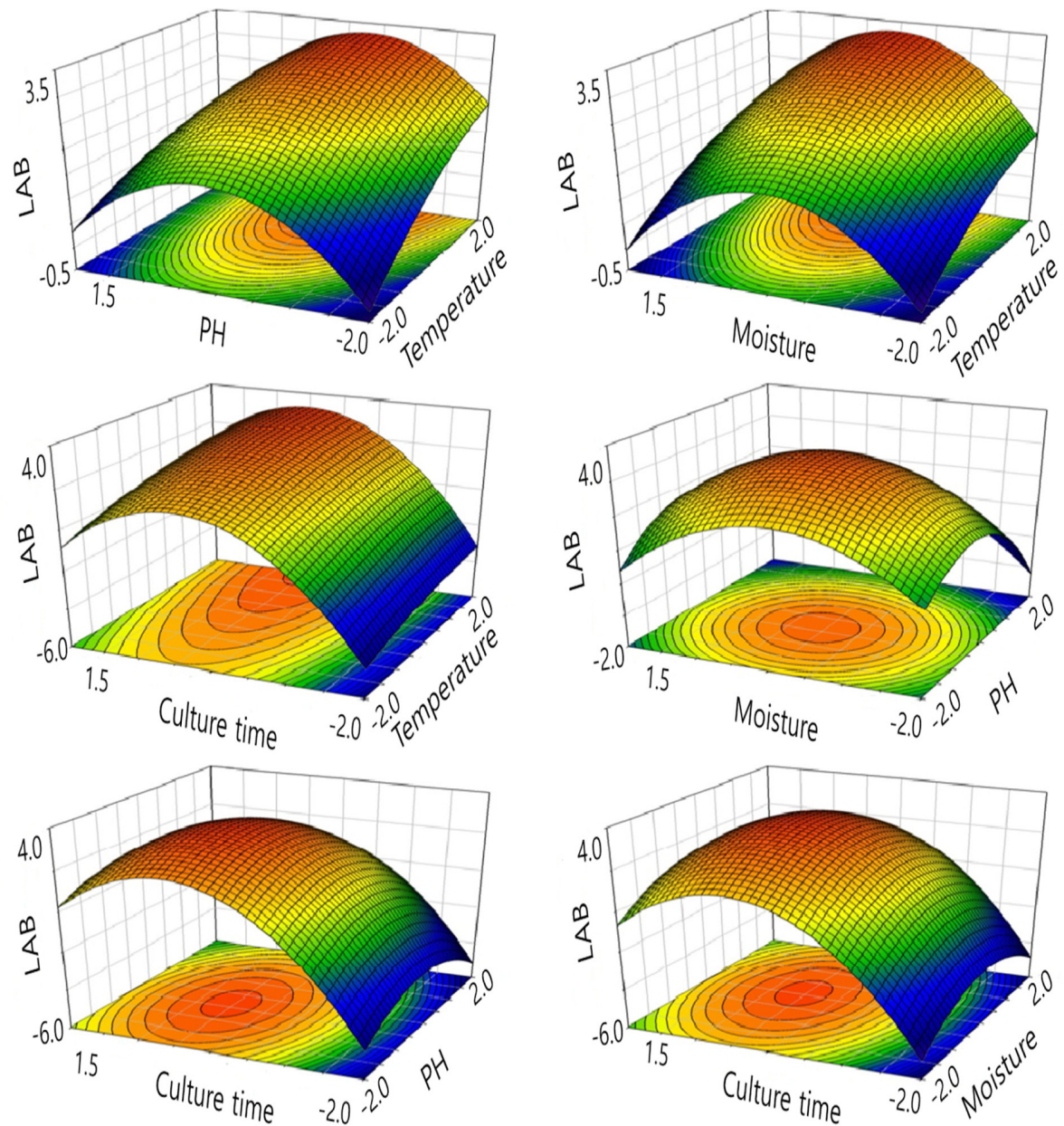

Fig. 3. Response surface plots and corresponding contour plot for the cell number of L. pentosus K1-23 in a mixed culture. 
production is as follows:

$Y=13.172-0.026 X_{1}-0.080 X_{2}+0.066 X_{3}+0.580 X_{4}+$ $0.015 X_{1} X_{2}+0.013 X_{1} X_{3}+0.004 X_{1} X_{4}+0.010 X_{2} X_{3}-0.026 X_{2} X_{4}$ $+0.016 X_{3} X_{4}-0.046 X_{1}^{2}-0.144 X_{2}^{2}-0.258 X_{3}^{2}-0.414 X_{4}^{2}$

As shown in Fig. 4, there was a quadratic curve effect for the varying levels of each factor, leading to the optimal point. The optimal point derived by the surface response model equation to maximize $\beta$-glucan production was $24.11^{\circ} \mathrm{C}, \mathrm{pH} 5.65$, moisture content of $60.08 \%$, and a culture time of 5.71 days, at which the expected maximum $\beta$-glucan production was $13.40 \%$. Gao et al. [26] reported that the optimal $\mathrm{pH}$ for cell growth and pullulan production by A. pullulans was 6.0, which is close to the optimal $\mathrm{pH}$ of 5.65 identified in our study for $\beta$-glucan production.

To compare the theoretical predicted values with actual production amounts, LAB cells and $\beta$-glucan production were tested for each optimal condition (Table 4). Using the optimal conditions for L. pentosus cell production $\left(37.84^{\circ} \mathrm{C}\right.$, $\mathrm{pH} 5.25$, moisture content of $60.82 \%$, and 6.08 days,) $3.15 \pm$ $0.10 \times 10^{8} \mathrm{CFU} / \mathrm{g}$ was achieved, which was close to the expected production value of $3.32 \times 10^{8} \mathrm{CFU} / \mathrm{g}$. Using the optimal conditions for $\beta$-glucan $\left(24.11^{\circ} \mathrm{C}, \mathrm{pH} 5.65\right.$, moisture content of $60.08 \%$, and culture time of 5.71 days), actual $\beta$-glucan production was $13.41 \pm 0.04 \%$, which was nearly the same as the expected value of $13.40 \%$.

In this study, we selected L. pentosus K1-23, which greatly inhibits various pathogenic bacteria, as well as A. pullulans NRRL 58012, which produces high amounts of immuneenhancing $\beta$-glucan, and optimized the medium composition and culture conditions for solid-phase mixed culture to achieve maximal production of LAB cell numbers and $\beta$-glucan. This mixed culture could be used as a highly
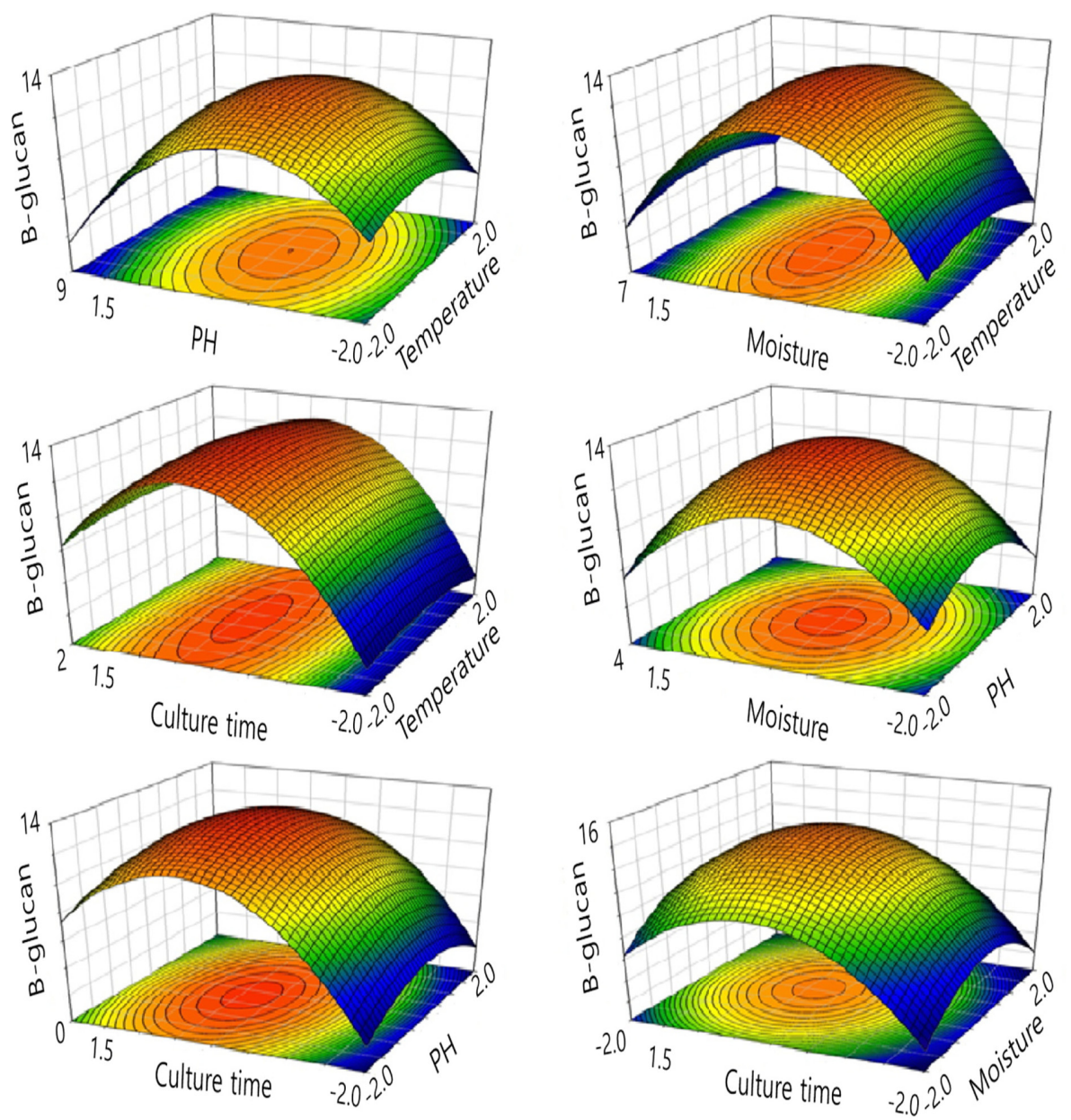

Fig. 4. Response surface plots and corresponding contour plot for $\beta$-glucan production by A. pullulans NRRL 58012 in a mixed culture. 
Table 4. Predicted and experimental values of LAB cell numbers and $\beta$-glucan produced by a mixture culture of $L$. pentosus K1-23 and A. pullulans NRRL 58012.

\begin{tabular}{|c|c|c|c|c|c|c|c|c|}
\hline \multirow[b]{2}{*}{ Run no. } & \multirow[b]{2}{*}{$\begin{array}{l}\text { Temperature } \\
\left({ }^{\circ} \mathrm{C}\right)\end{array}$} & \multirow[b]{2}{*}{$\mathrm{pH}$} & \multirow{2}{*}{$\begin{array}{c}\text { Moisture } \\
(\%)\end{array}$} & \multirow{2}{*}{$\begin{array}{l}\text { Culture time } \\
\text { (day) }\end{array}$} & \multicolumn{2}{|c|}{ Predicted values } & \multicolumn{2}{|c|}{ Experimental values } \\
\hline & & & & & $\begin{array}{l}\text { LAB cell number } \\
\left(\times 10^{8} \mathrm{CFU} / \mathrm{g}\right)\end{array}$ & $\begin{array}{c}\beta \text {-Glucan } \\
(\%)\end{array}$ & $\begin{array}{l}\text { LAB cell number } \\
\left(\times 10^{8} \mathrm{CFU} / \mathrm{g}\right)\end{array}$ & $\begin{array}{c}\beta \text {-Glucan } \\
(\%)\end{array}$ \\
\hline 1 & 37.84 & 5.25 & 60.82 & 6.08 & 3.32 & - & $3.15 \pm 0.10$ & $11.86 \pm 0.21$ \\
\hline 2 & 24.11 & 5.65 & 60.08 & 5.71 & - & 13.40 & $2.68 \pm 0.06$ & $13.41 \pm 0.04$ \\
\hline
\end{tabular}

efficient antibiotic substitute based on the combined effects of its anti-pathogenic and immune-enhancing activities.

\section{Acknowledgments}

This work (Grant No. C0213060) was supported by the Business for Cooperative R\&D between Industry, Academy, and Research Institute funded by the Korea Small and Medium Business Administration in 2013. H.C. Jeong was supported by the Basic Science Research Program through the National Research Foundation of Korea (NRF) funded by the Ministry of Education, Science and Technology (NRF2015R1D1A1A09059859). We thank to Dr. H. Punnapayak and S. Prasongsuk at Chulalongkorn University, Thailand for providing us 2 strains of A. pullulans.

\section{Conflict of Interest}

The authors have no financial conflicts of interest to declare.

\section{References}

1. Fuller R. 1989. Probiotics in man and animals. Appl. Bacteriol. 66: 365-378.

2. Hinton Jr A, Corrier DE, Ziprin RL, Spates GE, DeLoach JR. 1991. Comparison of the efficacy of cultures of cecal anaerobes as inocula to reduce Salmonella typhimurium colonization in chicks with or without dietary lactose. Poult. Sci. 70: 67-73.

3. Havenaar R, Brink BT, Veid JHJI. 1992. Selection of strains for probiotic use, pp. 209-224. In R. Fuller (ed.), Probiotics: The Scientific Basis. Chapmann \& Hall, London.

4. Adams MR, Nicholaides L. 1997. Reviews of the sensitivity of different foodborne pathogens to fermentation. Food Control 8: $227-239$.

5. Kim YO, Han SB, Lee HW, Ahn HJ, Yoon YD, Jung JK, et al. 2005. Immuno-stimulating effect of the endopolysaccharide produced by submerged culture of Inonotus obliquus. Life Sci. 77: 2438-2456.

6. Kimura Y, Sumiyoshi M, Suzuki T, Suzuki T, Sakanuka M. 2007. Effect of water-soluble low-molecular-weight $\beta-1,3-D-$ glucan (branch $\beta-1,6$ ) isolated from Aureobasidium pullulans 1A1 strain black yeast on restraint stress in mice. J. Pharm. Pharmacol. 59: 1137-1144.

7. Masuda Y, Matsumoto A, Toida T, Oikawa T, Ito K, Nanba H. 2009. Characterization and antitumor effect of a novel polysaccharide from Grifola frondosa. J. Agric. Food Chem. 57: 10143-10149.

8. Laroche C, Michaud P. 2007. New developments and prospective application for $\beta-(1,3)$ glucans. Recent Pat. Biotechnol. 1: 59-73.

9. Chan GC, Chan WK, Sze DM. 2009. The effects of betaglucan on human immune and cancer cells. J. Hematol. Oncol. 2: 25.

10. Zhou LD, Zhang QH, Zhang Y, Liu J, Cao YM. 2009. The shiitake mushroom-derived immuno-stimulant lentinan protects against murine malaria blood-stage infection by evoking adaptive immune-responses. Int. Immunopharmacol. 9: 455-462.

11. Queiroz LS, Nascimento MS, Cruz AK, Castro AJ, Moura Mde F. 2010. Glucans from the Caripia montagnei mushroom present anti-inflammatory activity. Int. Immunopharmacol. 10: $34-42$.

12. Sakaria T, Kaise T, Yadomae T, Matsabara C. 1997. Different role of serum components and cytokines on alveolar macrophage activation by soluble fungal $(1 \rightarrow 3)-\beta$-D-glucan. Eur. J. Pharmacol. 334: 255-263.

13. Muramatsu D, Iwai A, Aoki S, Uchiyama H, Kawata K, Nakayama Y, et al. 2012. $\beta$-Glucan derived from Aureobasidium pullulans is effective for the prevention of influenza in mice. PLoS One 7: e41399.

14. Bohn JA, Be Miller JN. 1995. $\beta$-(1-3)-Glucan as biological response modifiers: a review of structure-functioned activity relationship. Carbohydr. Polym. 28: 3-14.

15. Yoshiyuki K, Maho S, Masahiro S, Masahiro S, Toshio S. 2006. Effects of water-soluble low-molecular-weight beta1,3-D-glucan isolated from black yeast on tumor growth, liver metastasis and diet-induced allergy in mice. J. Pharma. Soc. Jpn. 126: 62-63.

16. Kimura Y, Sumiyoshi M, Suzuki T, Sakanaka M. 2006. Antitumor and antimetastatic activity of a novel watersoluble low molecular weight beta-1,3-D-glucan (branch beta-1,6) isolated from Aureobasidium pullulans 1A1 strain black yeast. Anticancer Res. 26: 4131-4141.

17. Yatawara L, Wickramasinghe S, Nagataki M, Takamoto M, 
Nomura H. 2009. Aureobasidium-derived soluble branched $(1,3-1,6)$ beta-glucan (Sophy beta-glucan) enhances natural killer activity in Leishmania amazonensis-infected mice. Korean J. Parasitol. 47: 345-351.

18. Miller GL. 1959. Use of dinitrosalicylic acid reagent for determination of reducing sugar. Anal. Chem. 31: 426-428.

19. Altschul SF, Madded TL, Schaffer AA, Zhang J, Zhang Z, Miller W. 1997. Gapped BLAST and PSI-BLAST: a new generation of protein database search programs. Nucleic Acids Res. 25: 3389-3402.

20. Kurtzman CP, Robnett CJ. 1998. Identification and phylogeny of ascomycetous yeasts from analysis of nuclear largesubunit (26S) ribosomal DNA partial sequences. Antonie Van Leeuwenhoek 73: 331-371.

21. Innis MA, Gelfand DH, Sninsky JJ, White TJ. 1990. PCR Protocols: A Guide to Methods and Applications. Academic Press, San Diego.

22. Gardes M, Bruns TD. 1993. ITS primers with enhanced specificity for basidiomycetes-application to the identification of mycorrhizae and rusts. Mol. Ecol. 2: 113-118.

23. Go E. 2012. Strain development and optimization of culture condition of Aureobasidium pullulans producing immune enhancer. MS Thesis. The University of Suwon, Republic of Korea.

24. Buyondo JP, Liu S. 2011. Lactic acid production by Lactobacillus pentosus from wood extract hydrolysates. J. Sci. Technol. Forest Prod. Process. 1: 38-47.

25. Todorov SD, Dicks LMT. 2007. Bacteriocin production by Lactobacillus pentosus ST712BZ isolated from BOZA. J. Microbiol. 38: 166-172.

26. Gao W, Kim YJ, Chung CH, Li J, Lee JW. 2010. Optimization of mineral salts in medium for enhanced production of pullulan by Aureobasidium pullulans HP-2001 using an orthogonal array method. Biotechnol. Bioprocess Eng. 15: 837-845. 